\author{
JOURNAL OF INFORMATION \\ SYSTEM AND TECHNOLOGY \\ MANAGEMENT \\ (JISTM) \\ www.jistm.com
}

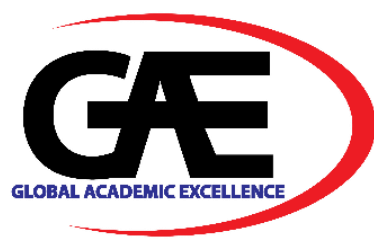

\title{
THE RELEVANCE OF NATIONHOOD KNOWLEDGE IN MALAYSIAN STUDIES COURSES: A CONVEYANCE FOR NATIONAL UNITY AND AN INTEGRATION OF UNIVERSITY STUDENTS' IDENTITY
}

\author{
Irma Wani Othman ${ }^{1}$, Mohd Sohaimi Esa ${ }^{2 *}$, Anna Lynn Abu Bakar ${ }^{3 *}$, Saifulazry Mokhtar ${ }^{4}$ \\ 1 Centre of The Promotion of Knowledge and Language Learning, Universiti Malaysia Sabah, Malaysia \\ Email: irma@ums.edu.my \\ 2 Centre of The Promotion of Knowledge and Language Learning, Universiti Malaysia Sabah, Malaysia \\ Email: msohaimi@ums.edu.my \\ 3 Centre of The Promotion of Knowledge and Language Learning, Universiti Malaysia Sabah, Malaysia \\ Email: annalynn@ums.edu.my \\ 4 Centre of The Promotion of Knowledge and Language Learning, Universiti Malaysia Sabah, Malaysia \\ Email: saifulazry.mokhtar@ums.edu.my \\ Corresponding Author
}

\section{Article Info:}

\section{Article history:}

Received date: 11.09 .2021

Revised date: 10.10 .2021

Accepted date: 15.11.2021

Published date: 30.11 .2021

\section{To cite this document:}

Othman, I. W., Esa, M. S., Abu Bakar, A. L., \& Mokhtar, S. (2021). The Relevance Of Nationhood Knowledge In Malaysian Studies Courses: A Conveyance For National Unity And An Integration Of University Students' Identity. Journal of Information System and Technology Management, 6 (23), 01-20.

DOI: $10.35631 / J I S T M .623001$

This work is licensed under CC BY 4.0

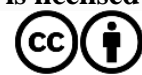

Copyright $\odot$ GLOBAL ACADEMIC EXCELLENCE (M) SDN BHD - All rights reserved

\begin{abstract}
:
This paper debates the relevance of knowledge of nationhood as a conveyance for national unity identity and integration of university students' self-identity in addressing the issues and challenges of the Covid-19 postpandemic era. In dissecting the significance of university student's understanding of the Malaysian Studies course, the thrust of this discussion perspective works on the two-pronged objectives of (1) identifying the relevance of national unity identity issues of the younger generation, and (2) examining the challenges of applying National Principles as self-identity integration of university students. The synthesis of the discussion was also embroidered on the nurturing of the national language in society and the issue of compliance with the country's constitution and laws. The qualitative approach utilises secondary data content analysis methods, namely the results of research in journals, reports, books and online news sources. The results of the study show that the course education of the nature of Malaysian Studies is a strong medium that can help understand the knowledge of nationhood and foster the retention of self-identity among students. The element of integration is also argued to place the relevance of university students to know the origin of a national identity and to avoid being influenced by external negative cultures. Naturally, each individual learns norms, values and habits through socialisation agents such as family, education, government and peers. Therefore, in the context of the relevance of learning
\end{abstract}


Volume 6 Issue 23 (November 2021) PP. 01-20 DOI: 10.35631/JISTM.623001 Special Issue: Foundation Program Education Post-Covid-19: Issues and Opportunities and teaching elements that contain aspects of Malaysian Studies, understanding the knowledge of nationhood is a critical agenda for the future of the country where the formation of national identity must be inculcated in every student to strengthen national unity.

Key words:

Knowledge of Nationhood, National Unity Identity, Integration

\section{Introduction}

The element of self-identity becomes an important component in a person where nature, uniqueness and specialness are the backbone and symbolises a person's personality in terms of culture, customs, language and religion. Self-identity holds the identity of a nation that is patriotic, true and genuine that is held by an individual. Recalling the words of Datuk Seri Utama Dr. Rais Yatim (2005), self-identity is the elements of life that describe the psyche of individuals and society (Othman, 2019c). In other words, this self-identity is defined as the identity of individuals, communities and nations that are of strength, tenacity and integrity that all parties are proud of (Othman, Ationg, Esa, Hajimin \& Abang Muis, 2021a). The personality and self-worth of an individual, society or country is something that is always connected and tied to an identity.

The main agenda in a country is to produce an original and clean individual identity. This is said so because this original and clean identity can be used as a basis and symbol of excellence and fame of a country. However, in the wake of the rapid current of modernity, a matter of concern is when an identity is at stake in religion, race and country. This is said so because today's young generation is known for their curiosity to try something new and is easily influenced by foreign cultures (Hamzah, Suandi, Hamzah \& Tamam, 2013). It is the responsibility of all parties in safeguarding the identity of the younger generation because they are the generation of hope for the country that will rule the government in the future. However, the present times have changed and have shown profound flaws especially in the matter of love for our own country and nation.

The deterioration of self-identity among the younger generation is not only from the attitude of ignorant thinking, but also stems from the attitude of a handful of people to spread untrue and false information to undermine the harmony of the younger generation about self-identity. This is said so because day by day there are fake and outrageous news shown to these younger generations. Therefore, the preservation of self-identity among the younger generation is a priority for all parties in maintaining unity in society and the country. What is closely related to self-identity is integration where it is one of the fields in maintaining the self-identity of the younger generation in strengthening national unity (Kirman, Hassan, Anwar, Mohd Khir \& Wan Jaafar, 2021).

Integration is defined as the merging of two or more races into one group or union and becomes the identity of a society. Malaysia is a country with a population of multi-racial backgrounds (Othman, Yusoff, Mohd Shah, Mokhtar, Abang Muis, Marinsah \& Marzuki, 2021b). The diversity of these races makes the practice of a way of life unique and distinctive. This diversity can also be observed through the diversity of language, economy, politics and social relations that often manifest their own uniqueness. As we all know, Malaysia has a multi-racial society. 


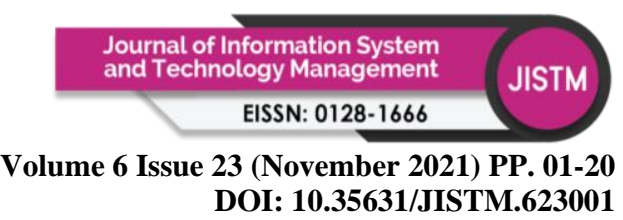

Special Issue: Foundation Program Education Post-Covid-19: Issues and Opportunities For example, the Malays, Indians and Chinese (Abang Muis, Esa, Ationg, Mohd Tamring, Hamid, Mokhtar \& Othman, 2021). In Sabah and Sarawak, there are various unique races such as the Kadazan, Iban, Murut, Bajau and many more (Lukin, Esa, Abang Muis, Ationg, Mohd Tamring, Othman, \& Mokhtar, 2021).

Integration also means the unification of a group of people of different backgrounds, regardless of race, ethnicity and religion into a bond of identity that combines the values of common good. Integration also serves to unite community groups through a common identity. This is said so because racial unity is the backbone of the country in ensuring the independence of a sovereign country can be achieved through time. In the context of the relevance of teaching and learning elements in Malaysian studies, understanding the knowledge of nationhood is an important agenda in the formation of national identity and should be inculcated in every Malaysian society from an early age to strengthen national unity.

\section{Methodology And Literature Review}

The qualitative approach utilises secondary data content analysis methods that are the results of research journals, reports, books and online news sources (Babbie, 2017; Creswell, 2014; Flick, 2014; Eriksson \& Kovalainen, 2016). In the context of this study, the method produces research data that shows the importance of Malaysian Studies course education as a critical medium that helps in recognising and fostering understanding of knowledge on nationhood in maintaining student's self-identity in the face of this challenging era of globalisation.

The writing of this paper uses rationality that provides a premise or foundation to debate the relevance of knowledge of nationhood as a vehicle for national unity identity and university student's self-identity in addressing the issues and challenges of the post-pandemic era of Covid-19. By taking such an approach, this writing then allows facts to be explained based on issues associated with actual events. This is done based on clear information from document analysis placing the importance of knowledge related to the knowledge of nationhood such as constitution, law and national principles applies as university level courses for the benefit of future national leadership.

\section{National Identity As A Conveyance For Strengthening University Student Unity}

The national identity displayed in Malaysia is more focused on unity among the multi-racial society in terms of various aspects. A built-in national identity can display the unity that exists between communities. Thus, the unity forged due to a sound understanding of history will be able to help avoid misunderstandings with each other. The main national identity of Malaysia is the Malaysian race which consists of many races that have their own unique identity that needs to be preserved (Sharif Adam, Othman, Hamid, Esa, Ationg, Lukin \& Mohd Tamring, 2021). In the context of the relevance of the knowledge of nationhood sown among the younger generation, understanding of national history is an important agenda in the formation of national identity and should be inculcated in every Malaysian society from an early age to strengthen national unity.

Among the main role of Malaysian Studies courses offered at universities is associated with the important role of the knowledge of nationhood content for the formation of national identity is to provide understanding to the younger generation related to national sacrifices, especially matters related to national independence (Esa, Ationg, Othman, Mohd Shah, Yusoff, Ramlie $\&$ Abang Muis, 2021a). This is important because an understanding of history of the country Copyright (C) GLOBAL ACADEMIC EXCELLENCE (M) SDN BHD - All rights reserved 


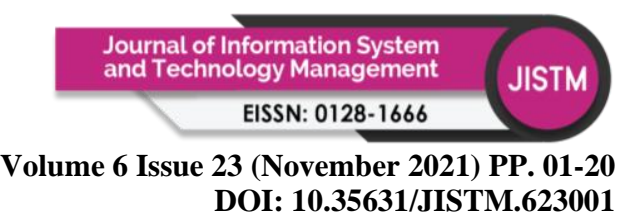

Special Issue: Foundation Program Education Post-Covid-19: Issues and Opportunities can shape the personality of the younger generation. This matter will also lead to the concern of university students as the backbone of the country towards their responsibilities to the nation and development of Malaysia. Therefore, the younger generation will be more open to work together in materialising the country's goals.

History can also instil the feeling of love for the country due to the content that provides knowledge and embracement to the Malaysian society (Abdul Hamid, Esa, Ationg, Othman, Sharif Adam, Mohd Tamring \& Hajimin, 2021). This leads to fostering a sense of belonging that will create a feeling that the country becomes everyone's common rights that needs to be defended. Apart from that, an understanding of the country's history is also important because it can be a reference to the younger generation in the formation of a multi-racial nation. For example, the event of $13^{\text {th }}$ May 1969 can be a reference to the heirs of the nation on the importance to maintain the inter-racial unity among the Malaysian community (Esa, Ationg, Othman, Raymond Majumah, Abu Bakar, Mohd Shah \& Yusoff, 2021b).

The nurturing of national identity is closely related to the understanding of history due to the society being inclined towards efforts to uphold the culture and heritage practiced and held in their lives. The formation of this identity is also through the formation of their lives that are founded by the cultural heritage practiced. Therefore, the importance of history in building this national identity will lead to the unification of the races that exist in Malaysia. National identity can also be nurtured through the spirit of patriotism and nationalism that exists due to the understanding of history. History has been a strength to society as a continuation in maintaining unity among them despite the influence of the technological world which can be a threat towards the unity that has been built (Sansalu, Esa, Karulus \& Mohd Tamring, 2015).

Among the aspects of historical understanding that needs to be considered by society is the understanding of social contract. This is said to be so because the social contract is one of the first steps in the creation of a national identity to achieve unity when viewed from the aspect of national history. Social contract is one of the main formulas that can form a national identity in Malaysia (Hassan, Angterian \& Yusop, 2017). Social contract is an agreement or consent reached together among the Malaysian community in terms of acceptance, understanding, respect and tolerance of the context or content of the status quo in achieving unity that aims to achieve independence. The social contract also becomes a symbol to the consensus of cultivating unity and was the first path opened by previous generations to the heirs of future generations. Therefore, society must make the history of acceptance of social contracts as a reference in the formation of national identity. This is said so because even though Malaysia has achieved independence, unity is not something that is easy to achieve because Malaysia is still struggling with the search for its proper identity.

In conclusion, social contract is a reference to the resolution of racial differences that can be seen from the aspect of the interests of their respective races. This is also to ensure that there are no discrepancies from time to time. As proof, this agreement and acceptance clearly illustrates that the Malays recognises the Chinese and Indians as citizens (Kamil \& Mohamad, 2020). As a result of this recognition, the Chinese and Indians have recognised the special position of the Malays from various aspects such as the privileges of the Malays, the sovereignty of the rulers, religion of Islam and the Malay language (Lukmanulhakim, 2020). 
Special Issue: Foundation Program Education Post-Covid-19: Issues and Opportunities National Identity And Significance Of Understanding The Knowledge Of Nationhood And Malaysian Studies Among The Young Generation

Education is a medium that helps in recognising and cultivating an understanding of history and the national language in the Malaysian society (Othman, 2021). This measure is the most effective measure which is also one of the measures is taken seriously by the government. This is clear in the provisions of the Education Act 1961 which has set the main thrust by implementing a uniform education system, where Malay language is set as the medium of instruction for schools, curriculum and examinations (Kamil \& Mohamad, 2020). Apart from that, Malay language is a compulsory subject for all types of national schools throughout the country. These thrusts are also the basis of the Rahman Razak Report as well as the Rahman Talib Report (Hassan, Angterian \& Yusop, 2017).

Education is also capable in shaping national identity as it can bridge the gap between multiracial societies. Education is a national system that meets the needs of growth or development from economic, social and political aspects. The application of history and the national language in the education system is in various levels of education such as primary, secondary and university (Musa \& Rodi, 2014). Among the education systems that have been worked on is the establishment of vision schools to form a national identity among students. The vision school is a combination of a national school, a Chinese national type school and a Tamil national type school. The combination of these schools will be located in a single complex where everyone will share all the infrastructure, and this allows for interaction between students of different races (Iberahim, Mahamod \& Mohammad, 2017).

The unity formed between them will increase the nature of tolerance with each other. This vision school also teaches students to learn to communicate in leading the development of the country in the future because students are the next generation. Next is to elevate the Malay language in education. One of the efforts implemented is through the educational programme, 'Memartabatkan Bahasa Malaysia Memperkukuhkan Bahasa Inggeris' (MBMMBI) (Dignifying the Malay Language, Strengthening the English Language) (Sharif Adam, 2019). This programme is implemented by allocating additional time for both subjects, namely 30 minutes to 90 minutes for Malay language and 60 minutes to 90 minutes for English. This programme aims to balance the use of both languages so that there is no bias issue that students can master one language only. This effort allows students to not only rely on the use of one language but also often use their mother tongue in communication in daily life.

The national identity in terms of the national language can also be maintained where students are wise enough to use the language fairly without using English only due to the challenges of globalisation. Education can also cultivate national identity by applying the slogan 'Bahasa Melambangkan Bangsa dan Bahasa Jiwa Bangsa' (Language Symbolises the Nation and The Language of the Nation's Soul) in the education system (Che Rodi, \& Musa, 2014). The creation of this slogan is one of the slogans that is applied in the education system to increase the spirit of patriotism which will enable students to hold fast to the national language. This slogan can also educate the students to elevate the Malay language as an intellectual language, language of knowledge and language of philosophy (Mohd Tohar, Ab Halim \& Ku Samsu, 2017). This is said so because only the mother tongue can form a civilisation language for a country. Therefore, unity can also be formed from the formation of the spirit of patriotism that has been built in students through the slogan (Abdul Hamid et al., 2021). 


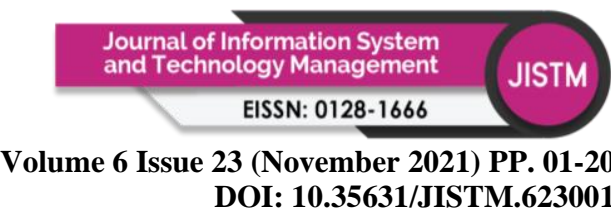

Special Issue: Foundation Program Education Post-Covid-19: Issues and Opportunities In addition, education also helps in cultivating national identity in the use of Malay language through Science and Mathematics subjects that are changed to Malay language from the use of English. This does not only increase students' interest in Science and Mathematics but also increases the percentage of use of Malay language in students (Ishak \& Mohamed, 2010). This can illustrate that Malay language can also be the language of knowledge in various streams, that is, Malay language also has the appropriate words in those streams. Teaching in Malay language can also facilitate the learning process and be able to speed up students' understanding of the subjects presented. The use of Malay language in the subjects of Science and Mathematics also allows students to know the diverse vocabulary that can be used in daily life which can also increase the growth of the use of Malay language in the communication system (Othman, Yusoff, Jupiter \& Mokhtar, 2021c).

Apart from that, teachers also play a role as nurturing agents that help students as targets to achieve unity through the education system. Teachers play a role in flexing students' thinking in shaping their personalities that contain national identity as their self-identity. Teachers are also able to expand the content of the curriculum which is considered to be narrow from the aspect of its scope by providing some exploitation of ideas from the thinking of teachers that have elements of inter-ethnic relations (Deraman, 2017). Learning in this country is further strengthened by making History as a core subject at the school level, which is a compulsory to master. Among the goals towards a deeper understanding of national identity is through the formation of students' understanding of the importance of ethnic relations through history subjects first. This effort can maintain the continuity of independence achieved by the country.

In short, the history of the country and the national language play a parallel role in giving national identity to the Malaysian society. While education is the main medium to apply the history and use of the national language to society, especially to the younger generation or the heirs of the country. National identity plays a very important role in shaping unity among the various races. As a result, if the national identity can be preserved well it will bring importance to the development of the country which is at the same time able to materialise the country's goals.

\section{Issues Of Cultivating The National Language In Society}

The national language of Malaysia is Malay, which is also known as the official language. The national language is a matter that cannot be disputed in terms of its function or role. Malay language as the official language is clearly recorded in Article 152 of the Federal Constitution which is the supreme law of Malaysia (Adam \& Abd Aziz, 2014). This national language is the main identity that the country wants to achieve after independence. This is said because the formation and selection of language as the national language can give personality to the country because during independence, Malaysia consists of a multi-racial society. The national language is also able to form the national identity by being the medium of communication to unite a society. At the same time, this matter will lead to the country's efforts to achieve success contributed by the multi-racial community agreement. The national language also gives identity to the community by giving an identity that reflects the culture of Malaysia, namely the national identity.

The national language used by the society of this country will remain as an identity to the society if the use of this language is extended from the aspect of network widely and more aggressively such as English, which is used as a second language for most countries (Ishak, \& Copyright (C) GLOBAL ACADEMIC EXCELLENCE (M) SDN BHD - All rights reserved 


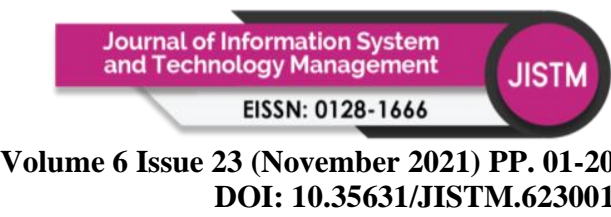

Special Issue: Foundation Program Education Post-Covid-19: Issues and Opportunities

Mohamed, 2010). Language also plays a very important role in development because the national language has become one of the communication tools between the Malaysian community. Therefore, society needs to preserve the national language because the growth of the language depends on the society that uses it as a lingua franca (Hassan, Angterian \& Yusop, 2017). The national language is the basis for society to form a national identity that leads to unity and brings to the interests of the country in achieving success.

The national language also serves as a link between society and the history of the country. The role of the national language can convey the knowledge of history into the soul of society through grammar as well as vocabulary used in providing an understanding of the historical events of the country. The Malay language is also a unique national identity that has the nature of being able to give beauty to the country's literature and art. The community can also recognise the Malay language as the national language because the Malay language has become the basis in various fields such as intermediate language, language of law, language of knowledge, language in matters related to religion, literary language and so on (Esa, Ationg, Othman \& Jupiter, 2021c). The community must preserve the national language by expanding its use because the Malay language was once the main language of transmission in the archipelago in the past.

Therefore, it is not appropriate for the Malaysian community not to recognise and use Malay language as the national language because it has been used since the rule of Malacca which was not only being the main language in the archipelago but the world, which is estimated at 300 million people uses Malay language at that point of time (Hassan, Angterian \& Yusop, 2017). The national language also plays its role as the national language by being a medium of interaction between various ethnic groups that can maintain harmony in society in social terms because the Malay language has its own decency. Therefore, misunderstandings can be avoided in society and able to interact well in achieving national success, especially in economic growth. Basically, the success achieved by the country on the factor of unity is fundamentally influenced by the factor of effective communication. This is said so because the community is able to cooperate in a conducive situation because the Malay language is a language that is easy to understand.

The national identity can also be clearly seen through its name which is the Malay language that describes the cultivating of the spirit of unity among the Malaysian community (Musa \& Rodi, 2014). The national language initially known as Malay language and has been renewed into Malaysia language which better describes the national identity because the national language carries the identity of the Malaysian nation. This national language should be dignified with the proper use of Malaysia language because there are a few communities that do not carry the national identity due to the challenge of technology that is increasing which affects the community using 'rojak' (mixture of a few languages) language (Mohd Tohar, Ab Halim \& Ku Samsu, 2017). Such things should be avoided because this national language is the identity of every society in this country.

\section{Issues Of Compliance With The National Law Constitution}

Each country will definitely have its own laws as well as Malaysia. Basically, the Federal Constitution is a supreme written law. This federal constitution was used since 1957 when Malaya had achieved independence (Esa et al., 2021c). In general, a total of 183 articles have been contained in the Federal Constitution. The Federal Constitution is said to be the supreme Copyright (C) GLOBAL ACADEMIC EXCELLENCE (M) SDN BHD - All rights reserved 


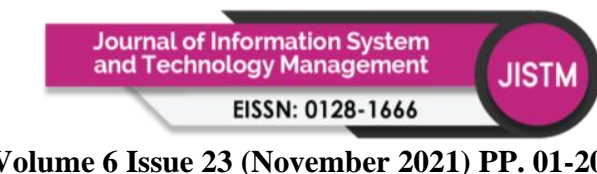

Volume 6 Issue 23 (November 2021) PP. 01-20 DOI: 10.35631/JISTM.623001

Special Issue: Foundation Program Education Post-Covid-19: Issues and Opportunities law because if any law is found to be in conflict with the Federal Constitution, it will continue to be repealed (Othman et al., 2021c). While in parliament, the constitution will be drafted as many as three hearings or called as a debate. The constitution or any act that has the support of 2/3 of the majority of parliamentarians, will only then be counted as a law (Ibrahim, Ationg, Esa, Abang Muis, Othman, Yusoff \& Mokhtar, 2021). For a country like Malaysia, this constitution is said to have bound the community by referring to only one law to solve the problem so that it does not conflict with each other.

The constitution is important because it can guarantee the peace of a country and the country's administrative system. For example, the Internal Security Act 1960 (ISA) is a preventive detention law that has been in force for a long in Malaysia (Othman, Ibrahim, Esa, Ationg, Mokhtar, Mohd Tamring \& Sharif Adam, 2021d). Through this act, anyone can be detained for 60 consecutive days by the police without any trial involving plans that seek to threaten national security (Othman et al., 2021d). With the existence of the constitution, the pattern of government and the division of power between the various government bodies as well as the general principles of the way power can be implemented. The existence of the Constitution is also said to be able to guarantee the safety and well-being of the people where there are human rights that allow freedom of speech to be used. Although given the right to speak, it is still subject to the act that has been provided.

Among them are the Internal Security Act and the Sedition Act 1948 (Othman et al., 2021d). In this context, it is clear that although citizens are allowed to express opinions and make expressions, it is still under the provisions of the law which means that if there is an element of sedition in particular which threatens the harmony of society, then the individual can be prosecuted according to the law. The reason a constitution is enacted is to ensure that the interests of all races are safeguarded by obtaining justice among all races. For example, in Article 149 it has been mentioned about an action that can be detrimental to public order (Ibrahim et al., 2021). Based on this matter, it has been mentioned that if there are any actions or words that are uttered so as to cause a feeling of malice and cause animosity between different races or other populations that are likely to cause violence. Therefore, if there is any provision that has the purpose to stop or prevent the act is valid even though it is not in line with any provision such as Article 5 which is personal liberty, Article 9 ban on deportation and freedom of movement, Article 10 which is freedom of speech, assembling, associating as well as the last Article 13 which is the Right to Property (Othman et al., 2021d).

It is common knowledge that the constitution is the supreme law of Malaysia. Even so, sometimes this constitution is challenged. This is because with the existence of today's society that has high knowledge in technology and education standards have tried to exceed the rights of social contracts that have been set. In Malaysia, the social contract refers to the agreement that has been reached among leaders of all races such as Indians, Malays and Chinese as well as the parties they represent from before Independence (Sansalu et al., 2015). Around 2010, several leaders such as Luqmanul Hakim Zul Razali and Maria, student activists were arrested while attending a peaceful rally (Othman et al., 2021d). As such, it has triggered an uncontrollable situation following protests from rally supporters. This is because in the Constitution has provided in Article 10 which allows every citizen to have the right to speak and express themselves and assemble peacefully without weapons (Othman et al., 2021d). The Malaysian government has also faced the challenge of upholding the existing Constitution in an effort to unite the people. This stems from the things that are raised. Therefore, the Copyright $\odot$ GLOBAL ACADEMIC EXCELLENCE (M) SDN BHD - All rights reserved 


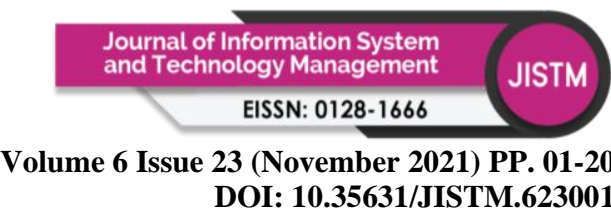

Special Issue: Foundation Program Education Post-Covid-19: Issues and Opportunities government has taken the initiative to constantly review the Constitution to ensure that it is suitable for society while maintaining unity between the races in Malaysia. Based on this situation, the government has had to amend the Acts contained in the constitution to follow the desires of the races in Malaysia. As known to the public, to build a peaceful and prosperous country with a united society is not something easy because it requires a community of various ethnicities who are able to work together and be united. Motivating agents are needed to form an understanding to continue to bring a positive aura to bring all communities together. One of the ways to strengthen unity among the races is by recalling the way Malaya achieved Independence (Musa \& Rodi, 2014). This aims to make the whole community to better appreciate the meaning of security that has been experienced. The National Principles of the nation should be practiced because it is the basis of unity which symbolises the unity of heart among the multi-racial community in Malaysia.

The existence of the National Principles is due to the bloody events of the racial riots on $13^{\text {th }}$ May 1969 (Ibrahim et al., 2021). This event has opened the eyes and minds of the multi-racial community in Malaysia to the importance of living in unity and abiding by the laws of the country. Through the attitude of racial unity sown among the community can help maintain political stability and good name of Malaysia on the world stage. The constitution gazetted in Malaysia is not to burden the people or deprive the people of their rights but to ensure harmony and cooperation can be achieved among the multi-racial community in Malaysia (Kamil \& Mohamad, 2020). Acts, ordinances and enactments are laws that have become complementary to the constitution. As Malaysians, we should play a big role in complying with all types of laws. The law is able to make all races in Malaysia live in unity without raising more racial issues that can trigger fights between them. This is because the law is the foundation to real life. When we as Malaysians do not abide by the law, it is possible that our country will not be able to be as peaceful as it is today. Despite different races and religions, the community needs to respect and see the uniqueness of a race without causing conflict.

\section{The Challenge Of Implementing The National Principles Through The Role Of Socialisation Agents}

The National Principles are used as a guide and way of life for the people of various races and ethnicities in Malaysia. There are five principles namely Belief in God, Loyalty to the King and Country, Supremacy of the Constitution, Rule of Law, as well as Good behaviour and Morality (Ibrahim et al., 2021). This principle is a pillar to the unification of the people by bringing the value of diversity and the formation of a peaceful nation. The National Principles are the core of unity in forming a nation regardless of religion and race. In this National Principles, if the community can embrace and understand it deeper, it is certain that issues such as $13^{\text {th }}$ May 1969 incident will not happen. In terms of law, the third and fourth principles need to be well understood so that society is always abide to the law. The fourth principle, the Rule of Law is said to be the medium to unite society.

The Rule of Law means that all citizens are equal before the law without racial discrimination and so on. The purpose of the National Principles is to further strengthen and restore racial unity in Malaysia due to the bloody events of $13^{\text {th }}$ May 1969 (Ibrahim et al., 2021). Malaysian are said to be a disciplined nation and ready to face challenges is the key to national peace and national unity. For example, the people's compliance with the law can be seen when almost all communities follow the instructions to stay at home and go out when necessary during the period of movement control. This clearly shows the personality of the people in Malaysia who Copyright $\odot$ GLOBAL ACADEMIC EXCELLENCE (M) SDN BHD - All rights reserved 


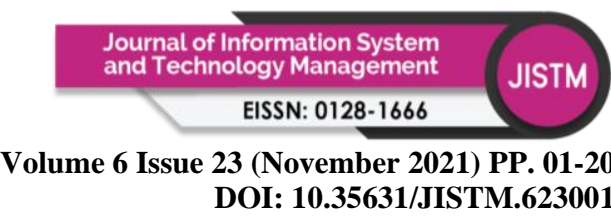

Special Issue: Foundation Program Education Post-Covid-19: Issues and Opportunities always abide by the law. Besides that, if the National Principles are not respected and underestimated, it will lead to the collapse of the country's democratic institutions. Not only that, it will also erode and destroy the meaning of the community unity value. It starts from the leader who needs to be a role model in nurturing the values of unity which is in line with compliance with the law.

Ultimately, the goals and National Principles need to be emphasised following the existence of the National Principles Act which is an important legal mechanism to curb problems or issues on unity among the races in Malaysia. The application of the National Principles of the country in various societies is the role of socialisation agents (Ibrahim et al., 2021). In social life, we constantly interact with other individuals in a group. Each of these individuals will learn norms and values or habits through the process of socialisation. This process is referred to as a socialisation agent which is a party that helps in implementing the socialisation process such as family, education, government and peers.

\section{Family And University Students}

The family is the first social group for an individual to mediate the culture of a society (Jaafar, Zain \& Eshak, 2020). This group is the closest and most powerful person in influencing our lives which makes it play an important role in applying the National Principles of the country in children from an early age. Children must know and embrace the National Principles of the country in order to give birth to patriotic spirit in children. Parents need to share details on the National Principles of the country as well as the benefits of it and how to embrace them. In the family agent, it is the parents who introduce the children to the patterns of behaviour, attitudes, beliefs, and values that prevail in the surrounding group (Stapa, Ismail \& Yusuf, 2012). Therefore, parents need to form a good child's character by constantly monitoring the development in terms of behaviour, conversation and thinking. Not only that parents also need to be a good example to be followed by their children as the saying goes, the apple does not fall far from the tree.

It is related to the National Principles of the country namely good behaviour and morality which means discipline, civility, decency and courtesy. This principle means maintaining behaviour in terms of religious, racial and cultural sensitivity in racial diversity in Malaysia (Zakaria \& Mohd Salleh, 2011). Parents are responsible for educating their children to always respect the sensitivities of a race from an early age. In community life, there are many races living in our surrounding and parents need to encourage children to mix with other races in order to be more familiar with the existing culture and create the nature of equality (Stapa, Ismail \& Yusuf, 2012). Therefore, children will have more respect for each other which leads to racial and religious harmony. For example, parents prefer to enrol their children in national schools where it consists of students of various differences such as background, ethnicity, race, etc. (Othman, Mohd Yusoff, Abdul Rahim, Puteh, Kasa, \& Roslan, 2016).

For the vernacular schools in our country such as Chinese and Tamil, it only encourages them to mix with their race only (Othman et al., 2016). Yet national schools provide great opportunities for children to interact with other races compared to vernacular schools. This allows them to learn to respect each other. In addition, the use of the same language further enhances children's tolerance and communication easily, regardless of race and religion. However, it is undeniable that there are some groups of parents and children who give unfair behaviour based on the diversity and differences that surround aspects of life in society. This Copyright (C) GLOBAL ACADEMIC EXCELLENCE (M) SDN BHD - All rights reserved 


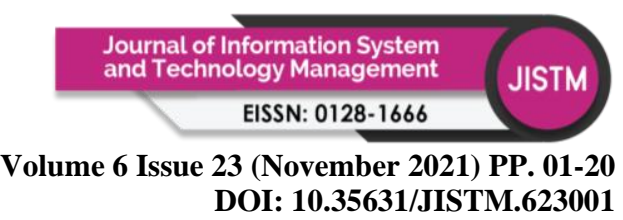

Special Issue: Foundation Program Education Post-Covid-19: Issues and Opportunities can raise the racial prejudice and in turn create racial discrimination as happened on $13^{\text {th }}$ May 1969 (Esa et al., 2021b). Therefore, this matter should be avoided because all this is the responsibility of parents in producing the child's thoughts that lead to peace and social wellbeing.

\section{Education And University Students}

Education involves the process of developing individual potential by imparting knowledge and skills to students (Md Idris, 2013). These agents must play a role in implementing the National Principles of the country at various levels of education such as schools and educational institutions. Educational socialisation can be categorised into three, namely student interaction with peers, teacher interaction with students and between school staff (Mohamed, \& Hassan, 2019). There are many factors that influence the development of children such as the school environment, the way the school is administered, the socialisation and the personality of the students themselves. It is undeniable that education can also change the thinking of individuals due to the situations and interactions that occur around them.

Education can cultivate how to embrace the National Principles of the country through the subjects of Civics and Citizenship Education as well as Moral Education at every school level in primary and secondary school (Ibrahim et al., 2021). The purpose is to ensure that all educators, especially students can understand the Country's National Principles. Not only students but teachers also need to be concerned by giving a clearer understanding the benefits of National Principles of the country. Educators should be intelligent to organise learning in a more interesting way such as quizzes or questions and answer sessions on National Principles to attract students to understand it more. Apart from academics in schools, co-curriculum activities related to the National Principles of the country should also be implemented in every school.

Currently, there are 6,621 National Principles Clubs established comprising 5,864 for primary schools and the rest for national secondary schools, while a total of 757 are from Chinese and Tamil national type primary and secondary schools (Ibrahim et al., 2021). The establishment of a National Principles Club is compulsory in every school to further enhance the understanding of the National Principles. The activities of the National Principles Club are implemented based on the five principles of the National Principles such as religious activities, patriotism involving the law as well as an understanding of the culture of a race. Many annual programmes of National Principles Club activities include poetry competitions, writing speeches related to the National Principles in each school. This can be embraced and in turn raise the spirit of patriotism among students. For example, competitions involving National Principles of the country are made an annual event in Ayer Keroh, Malacca (Ibrahim et al., 2021). The event consists of 60 participants competing against each other involving representatives of primary and secondary school students.

The competition included contest such as speech, story sharing, quizzes, and essay writing related to National Principles (Ibrahim et al., 2021). This programme inculcates the identity of young people in the embracement the Country's National Principles which in turn gives awareness of love for the country. Apart from that, the National Principles Club requires students to participate in camp activities to inculcate the noble values of the spirit of racial unity in students. In this programme students will be exposed to activities that involves the application of inter-racial cultures such as customs and taboos where students will better Copyright (C) GLOBAL ACADEMIC EXCELLENCE (M) SDN BHD - All rights reserved 


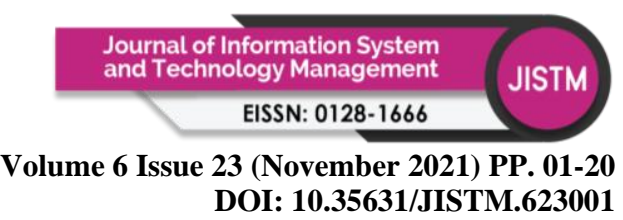

Special Issue: Foundation Program Education Post-Covid-19: Issues and Opportunities understand the customs of other races. Next, it involves traditional game activities as well as multi-racial cultural performances in our country.

This makes students more apprehended while being able to preserve the heritage from generation to generation. For example, on $27^{\text {th }}-29^{\text {th }}$ July 2018, Tun Aminah national secondary school, Johor Bahru held a camp involving the National Principles Club at the Johor State Level (Othman, 2019a). The programme was located at Recreation and Innovation Centre, Gunung Pulai 2, Kulai (Othman, 2019a). The programme was organised with the involvement of cooperation between the Johor State Education Department and the Department of National Unity and National Integration (Othman, 2019a). Through cross-cultural programmes, students can cultivate an attitude of cooperation between races regardless of background differences and then create a spirit of unity among students.

\section{Government And University Students}

The government is indeed responsible in cultivating the National Principles of the country in the people in various effective ways. This is because the way the country is administered influences the community's perspective in embracing the National Principles. The people need to maintain their self-identity to continue the well-being of the country which is also the responsibility of the government. The government took the initiative by organising programmes related to the Country's National Principles such as community activities. Joint celebration programmes such as Chinese New Year, Hari Raya by holding open house (Othman, 2019b). This involves cultural sharing such as getting to know customs, food, clothing and so on. In this matter it creates harmony of a diverse society regardless of race, culture and religion.

Following the National Principles of the country on decency and morality, which encourages the people to always have a fair, kind and just attitude in life. Besides that, the National Day and National Principles Day are celebrated every year but in year 2020, it was different with the theme "Caring Society" in line with the new norm environment of Covid-19 faced by Malaysia (Othman, 2019b). However, this programme was still going on according to standard operating procedures to maintain mutual safety. The people were also unable to watch at the location as usual but still had the opportunity to celebrate national day through television broadcasts and social media. In the 5 principles of National Principles is a unification to the diversity of the people in our country. This celebration is to commemorate and appreciate independence and peace. If the National Principles of the country continue to be embraced in the people, then our country will be able to maintain peace and prosperity in various aspects of life (Deraman, 2017).

The government needs to conduct various awareness campaign so that the people can fully embrace the National Principles. This campaign should be held in various departments such as the government, private sector and non-governmental organisations. The mass media is used as a platform to disseminate information to all walks of life. Not only that the printed materials such as newspapers and magazines need to be published more so that the people can embrace the National Principles of the country. For example, writing an article on the importance of embracing the National Principles of the country that needs to be applied in society. In addition, advertising on television by airing advertisements on the awareness of the National Principles of the country also helps by conveying an effective message. Apart from that, social media channels are also used as a faster and transcendent communicator of Copyright (C) GLOBAL ACADEMIC EXCELLENCE (M) SDN BHD - All rights reserved 
Volume 6 Issue 23 (November 2021) PP. 01-20 DOI: 10.35631/JISTM.623001

Special Issue: Foundation Program Education Post-Covid-19: Issues and Opportunities information such as Instagram, Facebook and Twitter (Othman et al., 2021c). Existing issues of modernity such as social media also bring harm to society in our country. This is because there are some irresponsible citizens who deliberately create provocations in the media by touching on issues of sensitivity such as insults or incitement to hate against the institution of the king (Othman et al., 2021c).

This conflicts with the concept of the National Principles of the country, namely Loyalty to the King and the Country. We, as the people must abide by the five principles of the nation which is the basis for the unity of the people. So far 209 reports have been received by the Royal Police in relation to insults against the Yang Di-Pertuan Agong. They used Facebook and Twitter to voice hatred as if the issue is taken lightly by some individuals (Berita Harian, 2019a). For example, pictures of the YDPA with obscene scribbles, using abusive words to bring down the dignity of the monarchy. Not only that, there are also those who dare to insult Islam through social media repeatedly such as insulting the Prophet Muhammad S.A.W and the Quran (Berita Harian, 2019b). Issues like this can provoke controversy among the people for not respecting the official religion in Malaysia. Therefore, the government needs to tighten the relevant laws such as the Sedition Act 1948 which is adopted by the government (Othman et al., 2021d). The guilty parties need to be punished more severely so that their people do not repeat past offenses. In addition, this method can produce people who are loyal to religion and obedient to the law in line with the National Principles of the country, namely Belief in God and the Rule of Law.

\section{Peers And University Students}

In subsequent developments, individuals will interact with peers who came from other people's families. Peers are also the closest persons after the family, and they can either be neighbour's friend, school friend and so on (Jalaluddin, Kasdan \& Ahmad, 2010). Although family is a strong socialising agent, one's behaviour will change after entering the school environment where they spend more time with new friends. Thus, children will learn to interact with peers who are like them in terms of age of experience, as well as thinking and so on. In the adolescent phase, they have a high sense of curiosity and the nature of wanting to try something new making the children more easily influenced by people around them (Jalaluddin, Kasdan \& Ahmad, 2010). There are three main factors that influences the socialisation of peers, namely the factors of suggestion, imitation and sympathy and these can shape the child's personality (Hamzah et al., 2013).

At present, the younger generation seems lacking in embracing the National Principles of the country compared to the previous generation, especially embracing the fifth principle which is the Good Behaviour and Morality. The fifth principle shows concern in the humanitarian aspect so that every citizen can respect each other for the common social well-being (Stapa, Ismail \& Yusuf, 2012). We can see many young people do not care about the need to have polite speech and courtesy. Nowadays, many young people use abusive, impolite words that have become a habit in children's lives. For example, there are a handful of those who do not respect parents and teachers as if the importance of the value of respecting others no longer exists. This can be seen closely by many educators in schools, and other educational institutions feel aggrieved about the rude attitude of students so unashamedly voicing their dissatisfaction such as fighting, breaking school rules and so on (Zakaria \& Mohd Salleh, 2011). 


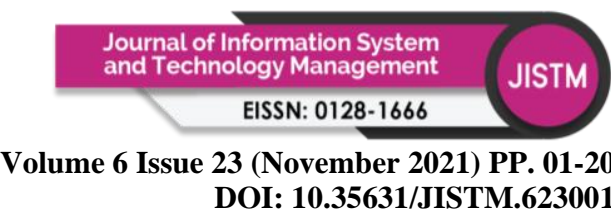

Special Issue: Foundation Program Education Post-Covid-19: Issues and Opportunities The following proves peers have a great influence on an individual's behaviour. Therefore, responsibility as a peer is needed in embracing the National Principles of the country through attitudes, thoughts, interests and appearances. Peers need to attract individuals to participate in activities related to society, that is implemented in schools, like sports (Aboo Talib @ Khalid, Shiratuddin, Hassan, Abdul Rahman \& Abdul Rahman, 2018). Usually, such programmes are more fun by involving interesting events such as solidarity runs, tele-match games, traditional games and so on. This indirectly encourages the spirit of unity because everyone can interact with the various races in our country. Not only that peers who set a good example can be emulated by an individual such as respecting parents and friends, friendly and always maintaining good language speech, can change the behaviour of the individual (Othman et al., 2016). Therefore, we as individuals need to be wise in choosing friends who can bring more benefits than disadvantages so as not to be influenced by the negative elements from friends.

In this case, parents also need to monitor their child's development, including the friends they have. They should always be given advice on how peer's influence can damage one's personality. Therefore, the identity of every citizens is incomplete if they cannot embrace the National Principles in order to maintain the harmony of society. Being polite, good moral and identity comes from a personality of pure values (Othman et al., 2016). Thus, the formation of a person's identity can be maintained through the people around them where they are able to strengthen their identity without compromising what has been learned in a person. Overall, socialisation agents are very important in maintaining the embracement of the National Principles of the country, especially in facing various issues and challenges in our country (Othman et al., 2016). These issues lead to controversy such as touching on racial, religious and ethnic sensitivities. Various efforts need to be done to protect and educate the people's souls towards patriotism based on the National Principles. Therefore, all socialisation agents must be intelligent in making decisions and always work together to address any problems to strengthen national unity from one generation to another.

\section{Maintaining Of Student Self-Identity}

The preservation of student self-identity begins with integration that serves as an agent to ensure that the current generation recognises the origins of a national identity and can avoid the current generation from being influenced by external cultures. However, we can see that the current generation has lost a lot of self-identity. This is because the current generation has been influenced by western culture, for example, the life of hedonism that is often prevalent among adolescents in Malaysia (Hamzah et al., 2013). A life of hedonism means making pleasure the ultimate goal of life (Hamzah et al., 2013). This is in stark contrast to the way Malaysians are educated, especially Muslims. This is said so because the influence of this hedonism not only damages the pure values of an individual, but also destroys identity. This integration also helps in giving awareness to the generations that is quickly being carried away with western culture.

The surrounding community can reprimand or warn those who have lost their self-identity and who have been influenced by foreign cultures to immediately leave the culture that tarnishes the identity of the community. As highlighted in the previous discussion, this self-identity can also be maintained with an embracement of the National Principles of the country. National Principles not only forms the self-identity but also becomes the mould of national integration (Ibrahim et al., 2021). This is said so because the National Principles of the country are the Copyright (C) GLOBAL ACADEMIC EXCELLENCE (M) SDN BHD - All rights reserved 


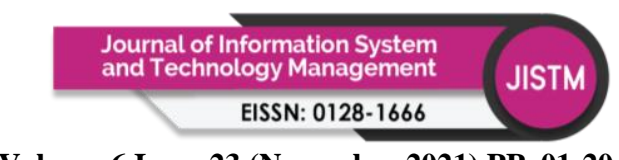

Volume 6 Issue 23 (November 2021) PP. 01-20 DOI: 10.35631/JISTM.623001

Special Issue: Foundation Program Education Post-Covid-19: Issues and Opportunities guidelines and pledges of all Malaysians. Then the National Principles can ensure that the nation's children are always aware of the importance of self-identity and national integration. Embracement of National Principles can increase the spirit of patriotism in today's youth (Lukmanulhakim, 2020). The word of unity enacted in the National Principles can unite the community in Malaysia. This creates an equality and the existence of unity among adolescents. As a result, awareness of self-identity in adolescents can be increased.

Preservation of self-identity can also be worked on by practicing 'Salad Bowl' in celebrating the differences that exist in society (Othman et al., 2021c). The 'Salad Bowl' is a cultural idea and metaphor in how communities with different racial backgrounds can integrate cultures and at the same time maintain the identity of their separated races (Othman et al., 2021c). It is amazing that this cultural idea differs from the idea of 'Melting Pot' because the melting pot combines parts into a whole. The concept of the Salad Bowl cultural idea is known as the cultural mosaic or 'Salad Thrown' in Canada (Othman et al., 2021c). In this salad bowl concept, different cultures are grouped and united. For example, the salad ingredients with various types of vegetables and fruits that are used for salad dish, but the shape and name of the salad ingredients can still be identified when combined. Such is the assumption in the idea of a salad bowl culture when different cultures are grouped, but do not change nor form a homogeneous culture.

One such culture retains its own identity, quality and privilege even when collected in the same union (Othman et al., 2021c). Our society needs to be a 'Salad Bowl' in celebrating differences to strengthen the self-identity of the current generation. However, it is difficult for society today to make unification when unification in the religious level is impossible. This is because the similarity of religion is not from a matter of spirituality alone, but also on the ethics and morals of an individual. This unification can only be accomplished when the community is at the level of consciousness and agrees to unite. Society will be united if it has awareness and knowledge about the unification of a nation. Therefore, the community needs to be wise in materialising this Salad Bowl cultural idea. This is because the Salad Bowl concept can maintain the self-identity of the current generation and can repel external elements easily.

The national language is the source of the formation of national identity in the context of the Malaysian race (Sharif Adam, 2019). The construction of the identity of the current generation should be nurtured through the national language, namely Malay as the official language of Malaysia (Mohamed \& Hassan, 2019). By this, racial unification and unity can be sown and prospered. In year 2003, the government has informed the people about the implementation of the Teaching and Learning of Science and Mathematics (PPSMI) in secondary and national schools in the country (Ishak \& Mohamed, 2010). This learning and teaching are taught in English. It is not a problem if one is learning and mastering a foreign language. However, if the Malay language itself is put aside, then the dignity of the Malay language itself is lost. Thus, the self-identity of the people themselves collapsed because they had put aside their National language.

The mindset of Malaysians themselves who consider that the Malay language cannot build its own reputation in shaping a developed and forward-thinking mind. Who else but our own society is striving to uphold the Malay language as the national language? For example, Germany had chosen Arabic as its national language and spoken language in the order of learning and teaching in Andalusian times in Europe. However, its students lacked in mastering Copyright (C) GLOBAL ACADEMIC EXCELLENCE (M) SDN BHD - All rights reserved 


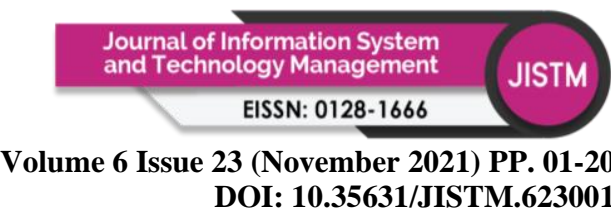

Special Issue: Foundation Program Education Post-Covid-19: Issues and Opportunities the subjects of Science and Mathematics. Next, Germany had to convert Arabic to Latin, but the same thing happened. During the First World War, the Germans changed their official language to their mother tongue which was German. Thus, we can see how strong the identity of the German community is and so much so they created their own sophisticated technology with the use of their own national language.

During the reign of Sriwijaya, it was proven that the glorious Malay language became the language of communication (Hassan, Angterian, \& Yusop, 2017). This is an amazing situation when scholars from China chase to gain knowledge in Palembang and Malay is the only language spoken in the archipelago (Hassan, Angterian, \& Yusop, 2017). In an effort to maintain this identity, the Malay language must be used properly and widely in all fields in Malaysia, as well as in the public sector or the private sector. This is to balance the practice with many countries in the future that speak their mother tongues as their main language of communication. Once again, the element of self-identity plays a role in uniting the souls in the country because self-identity of the individual, society and nation. The Malaysian flag or Jalur Gemilang (Stripes of Glory) is symbolic of our country's identity and sovereignty (Deraman, 2017). It is sad if the Jalur Gemilang is tarnished by any party who disrespect the country and do as they please.

Unity and the spirit of love for the country must be embedded in the souls of all people to ensure harmony and prosperity continue to remain, regardless of religion, race and culture (Adam \& Abd Aziz, 2014). The Jalur Gemilang that is waved majestically on vehicles, courtyard, in offices and on premises can enhance the identity of the generation and signify that this country belongs to us completely. Therefore, the campaign to fly the Jalur Gemilang needs to be intensified in order to provide awareness to the community who are being neglected by foreign cultures. The spirit of flying the Jalur Gemilang needs to be nurtured from an early age in order to form a fertile identity in our generation. The Jalur Gemilang also symbolises the loyalty of patriotism to the country, making it a close agent in maintaining the identity of the homeland (Abdul Hamid et al., 2021). There is no denying that technology shapes society's thinking, yet it is best if we can maintain our identity without the threat of this rapid globalisation.

The provisions of this Constitution can also be used as a basis for the preservation of national identity. This is said so because the importance of politics among the elements outside the educational process can be a change in building unity and maintaining the identity of the current generation. The education process should embed the doctrine of racial unity however, this effort must have the support and encouragement of those who are strong in the implementation of government policies. This is because it is enacted in the Federal Constitution of our country. Community thinking needs to be produced to create the nature of acceptance of the main culture in Malaysia. The existence of the Federal Constitution is to be a source of philosophy of thought of the indigenous tradition so that culture continues to be highly respected in our government (Ibrahim et al., 2021). This is said so because the National Cultural Policy and Idealism are enacted in the content of the National Principles (Ibrahim et al., 2021). This can maintain our identity in line with our desire to build unity in Malaysia.

Good politics and keeping morality and integrity have a tendency in sowing unity and identity of the true child of the land (Othman et al., 2021d). Good politics also has an ideology in defending the integrity and identity of generations from being influenced by colonial culture. Copyright $($ C GLOBAL ACADEMIC EXCELLENCE (M) SDN BHD - All rights reserved 
Special Issue: Foundation Program Education Post-Covid-19: Issues and Opportunities The abuse of power can destroy the unity of society and the country. A series of educational changes implemented in a chaotic social environment can cripple unity and the spirit of national identity. Therefore, the provisions of the constitution are very important in preserving the identity of the present generation.

\section{Concluding Thoughts:}

In the overall context of the discussion of this paper, the relevance of the elements of learning and teaching that contain aspects of Malaysian studies where the understanding of knowledge of nationhood is an important agenda in the formation of national identity. This needs to be inculcated in every Malaysian society from an early age to strengthen national unity is associated with the importance of the younger generation or university students in taking responsibility as a group that develops the people and the country (Mohd Tohar, Ab Halim \& $\mathrm{Ku}$ Samsu, 2017). The society has placed high hopes on the youths, the majority of whom come from university graduates in managing the administration of the country in the future. It is very important for university students to meet the criteria that must be present in order to contribute to society and the country.

Among the values required in university students is a strong sense of self-identity. This identity is very important in the effort to build and develop the nation and racial unity in Malaysia to be united. The people expect university students in defending the independence and sovereignty of the country where they need to embrace and practice all the National Principles as their way of life. Other than that, in developing a generation that is self-reliant to lead the country, it is necessary to strengthen their values of life guided by Eastern culture and continue to strengthen inter-racial unity (Lukin et al., 2021). It is frustrating when the university students we hope for in developing the country drift in this increasingly challenging world and easily follow the western culture that destroys their self-identity. It is worrying if young people forget their own origins. Therefore, university students cannot be easily trampled by foreign cultures.

The synthesis of the above discussion is also embroidered with discussions on the nurturing of the national language in society, and the issue of compliance with the country's constitution and laws. In conclusion, the discussion presented in this paper debates the relevance of knowledge of nationhood as a vehicle for national unity identity and integration of university students' self-identities in addressing the issues and challenges of the Covid-19 post-pandemic era. In the context of unravelling the significance students' understanding of Malaysian studies, the perspective of this discussion focuses on the relevance of national unity identity issues of the young generation, as well as linking it to the challenges of applying National Principles in ensuring the integration of young people, especially among university students. This proves that Malaysian Studies course education is a medium that helps in recognising and fostering an understanding of knowledge of nationhood in the maintenance of students' identity in order to face this challenging era of globalisation.

\section{Acknowledgement}

This article is part of the UMS collaborative publishing grant sponsorship funded by Global Academic Excellence (GAE). The authors would like to express their deepest heartfelt appreciation to Global Academic Excellence (GAE) for providing funding this publication. 


\section{References}

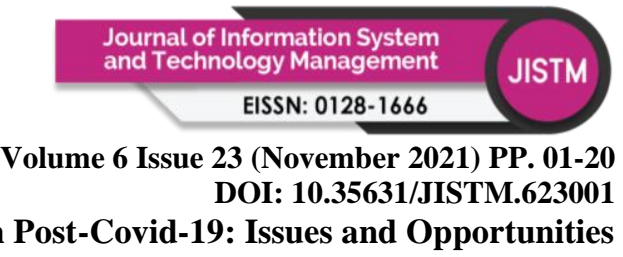

Abang Muis, A. M. R., Esa. M. S., Ationg, R., Mohd Tamring, B. A., Hamid, J. A., Mokhtar, S., \& Othman, I. W. (2021). Konsep Integrasi Etnik dari Perspektif Pembangunan Berteraskan Islam di Malaysia. International Journal of Law, Government and Communication, 6(23), 104-114.

Abdul Hamid, J., Esa, M. S., Ationg, R., Othman, I. W., Sharif Adam, S. D., Mohd Tamring, B. A., \& Hajimin, M. N. H. H. (2021). Penerapan Patriotisme Dalam Kalangan GuruGuru Sejarah Sekolah Menengah Di Sabah. International Journal of Law, Government and Communication, 6(23), 42-56.

Aboo Talib@ Khalid, K., Shiratuddin, N., Hassan, S., Abdul Rahman, Z. S., \& Abdul Rahman, N. L. (2018). Belia dan Sosialisasi: Tingkahlaku Relatif dan Perspektif Terhadap Media Baru. Jurnal Komunikasi Malaysian Journal of Communication 34(3), 208-225.

Adam, R., \& Abd Aziz, M. K. N. (2014). Pendaulatan Bahasa Melayu sebagai Bahasa Kebangsaan dan Bahasa Ilmu di Malaysia: Sejarah dan kedudukan masa kini. Kangar: Universiti Malaysia Perlis.

Babbie, E. (2017). The basics of social research (7th Ed.). Boston, MA: Cengage Learning.Berita Harian. (2019a). PDRM teliti semua laporan diterima kes hina YDP. Received from

Agonghttps://www.bharian.com.my/berita/nasional/2019/04/552587/pdrm-teliti-semualaporan-diterima-kes-hina-ydp-agong.

Berita Harian. (2019b). Penjaja dipenjara 30 bulan hina nabi, agama Islam dan kematian. Received from https://www.bharian.com.my/berita/kes/2019/08/593290/penjajadipenjara-30-bulan-hina-nabi-agama-islam-dan-kematian-adib

Che Rodi, R., \& Musa, H. (2014). Bahasa Melayu Bahasa Negara Bangsa Malaysia. Mahawangsa 1(2), 257-272.

Creswell, J. W. (2014). Research design: Qualitative, Quantitative, and Mixed Methods Approaches. Sage, Oaks.

Deraman, A. A. (2017). Pemerkasaan Bahasa Melayu di Negara Bangsa Malaysia Merdeka. Ipoh: Muzakarah Sultan Nazrin Muizzuddin Shah.

Eriksson, P., \& Kovalainen, A. (2016). Qualitative Methods in Business Research. 2nd ed. London, Thousand Oaks, New Delhi and Singapore: Sage.

Esa, M.S., Ationg, R., Othman, I.W., Mohd Shah, M. K., Yusoff, M. S., Ramlie, H.A., \& Abang Muis, A. M. R. (2021a). Evolusi Kursus Teras Universiti: Dari Sejarah Pembentukan Bangsa Malaysia Ke Penghayatan Etika Dan Peradaban. International Journal of Education, Psychology and Counselling, 6(39), 166-181.

Esa, M. S., Ationg, R., Othman, I. W., Raymond Majumah, A. S. A., Abu Bakar, A. L., Mohd Shah, M. K., \& Yusoff, M. S. (2021b). Gaya Kepimpinan Tun Razak Menjana Aspirasi Celik Minda Politik Dalam Kalangan Pelajar Institusi Pengajian Tinggi Di Malaysia. Journal of Islamic, Social, Economics and Development, 6(38), 30-44.

Esa, M. S., Ationg, R., Othman, I. W., \& Jupiter, H. (2021c). Isu Dan Cabaran Bahasa Melayu Sebagai Bahasa Kebangsaan Di Ambang Kemerdekaan Tanah Melayu. International Journal of Education, Psychology and Counseling, 6 (41), 111-125.Flick, U. (2014). An Introduction to Qualitative Research (5th Ed.). SAGE, London.

Hamzah, S. R., Suandi, T., Hamzah, A., \& Tamam, E. (2013). Pengaruh Rakan Sebaya ke atas Tingkah Laku Hedonistik Belia IPT di Malaysia. Jurnal Teknologi, 63(1), 17-23.

Hassan, H. I. M., Angterian, S. M., \& Yusop, M. S. (2017). Kegemilangan Bahasa Melayu sebagai Lingua Franca. Jurnal Kesidang, 2(1): 18-30. 


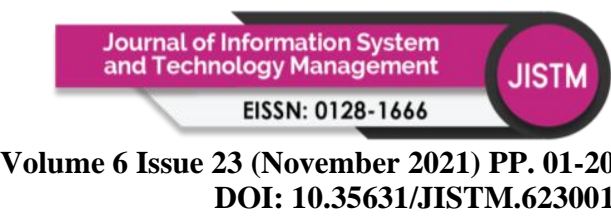

Special Issue: Foundation Program Education Post-Covid-19: Issues and Opportunities Iberahim, A. R., Mahamod, Z., \& Mohammad, W. M. R. W. (2017). Pembelajaran Abad Ke21 Dan Pengaruhnya Terhadap Sikap, Motivasi Dan Pencapaian Bahasa Melayu Pelajar Sekolah Menengah. Jurnal Pendidikan Bahasa Melayu, 7(2), 77-88.

Ibrahim, M. A., Ationg, R., Esa, M. S., Abang Muis, A. M. R., Othman, I. W., Yusoff, M. S., \& Mokhtar, S. (2021). Pengetahuan Terhadap Ilmu Perlembagaan, Undang-Undang Dan Rukun Negara Dalam Konteks Kepimpinan: Kajian Kes Pelajar Universiti Malaysia Sabah (UMS). Journal of Islamic, Social, Economics and Development, 6(38), $45-59$.

Ishak, T., \& Mohamed, M., (2010). Pengajaran Dan Pembelajaran Sains Dan Matematik Dalam Bahasa Inggeris (PPSMI): Suatu Isu Berulang. Jurnal Teknologi, 53(Sains Sosial), 95106.

Jaafar, N. F., Zain, A., \& Eshak, Z. (2020). Peranan Ibu Bapa Dalam Membantu Perkembangan Sosial Kanak-Kanak Melalui Aktiviti Bermain Semasa Perintah Kawalan Pergerakan. Jurnal Pendidikan Awal Kanak-kanak Kebangsaan (Special Issue),9, (2020), 52-60.

Jalaluddin, N. H., Kasdan, J., \& Ahmad, Z. (2010). Sosiokognitif Pelajar Remaja Terhadap Bahasa Melayu. GEMA Online ${ }^{\circledR}$ Journal of Language Studies, 10(3), 67-87.

Kamil, I. M. M., \& Mohamad, M. (2020). Cabaran Pemerkasaan Bahasa Melayu Dalam Usaha Mencapai Negara Bangsa di Malaysia. Asian People Journal (APJ), 3(2), 181-191.

Kirman, N. S., Hassan, M. M., Anwar, F. H., Mohd Khir, A., \& Wan Jaafar, W. M. (2021). Faktor Sosialisasi dalam Mempengaruhi Tingkah Laku Individu. Malaysian Journal of Social Sciences and Humanities, 6 (1), 106-118.

Lukin, S. A., Esa, M. S., Abang Muis, A. M. R., Ationg, R., Mohd Tamring, B. A., Othman, I. W., \& Mokhtar, S. (2021). Kaedah dan Cabaran Dalam Mengurus Hubungan Etnik di Malaysia. International Journal of Law, Government and Communication, 6(23), 115124.

Lukmanulhakim, N. N. (2020). Kaedah Pembentukan Identiti Nasional dalam Universiti Awam di Malaysia. Jurnal Peradaban Melayu, 15: 1-9.

Md Idris, M. R. (2013). Memartabatkan Bahasa Melayu Melalui Pendidikan Dan Mendepani Cabaran Globalisasi. Malaysian Journal of Youth Studies, 4(12), 207-220.

Mohd Tohar, S. N. A., Ab Halim, A., \& Ku Samsu, K. H. (2017). Pengukuran Tahap Pemartabatan Bahasa Kebangsaan dalam kalangan Mahasiswa Institusi Pengajian Tinggi. Journal of Language Studies, 17(2), 105-122.

Mohamed, N. A., \& Hassan, N. A. (2019). Pengukuhan Bahasa Melayu Sebagai Bahasa Perpaduan di Institusi Pengajian Tinggi Swasta. Malaysian Journal of Social Sciences and Humanities (MJSSH), 4(4), 19-28.

Musa, H., \& Rodi, R. C. (2014). Peranan Bahasa Melayu dan Legasi Sejarah Penubuhan Malaysia dalam Penyemaian Cinta akan Negara Bangsa Malaysia. Pertanika Mahawangsa, 1(1),19-42.

Othman, I. W. (2021). Shifting the National Higher Education Landscape in Facing Current Challenges and Marketability Strategies of Covid-19 Pandemic Era Graduates. Journal of Tourism, Hospitality and Environment Management, 6 (25), 139-156.

Othman, I. W., Ationg, R., Esa, M. S., Hajimin, M. N. H. H., \& Abang Muis, A. M. R. (2021a). Signifikasi Prinsip Hidup Merujuk Keterkaitan Agama, Budaya, Amalan Kepercayaan dan Wawasan Dunia Secara Keseluruhan (Worldview): Motif Ekspatriasi Ahli Akademik Islam dalam Membina Kerjaya di Malaysia. International Journal of Law, Government and Communication, 6(23), 85-103.

Othman, I. W., Yusoff, M. S., Mohd Shah, M. K., Mokhtar, S., Abang Muis, A. M. R., Marinsah, S. A., \& Marzuki, M. (2021b). Signifikasi Keunikan Diversiti Budaya Copyright $\odot$ GLOBAL ACADEMIC EXCELLENCE (M) SDN BHD - All rights reserved 
Volume 6 Issue 23 (November 2021) PP. 01-20 DOI: 10.35631/JISTM.623001

Special Issue: Foundation Program Education Post-Covid-19: Issues and Opportunities Masyarakat Majmuk Disulami Keharmonian, Disantuni Perpaduan Sebagai Nilai Tambah Kepercayaan Keluarga Dan Pemangkin Diaspora Pelajar Antarabangsa Melanjutkan Pengajian Ke Malaysia. International Journal of Education, Psychology and Counseling, 6(39), 01-28.

Othman, I. W., Yusoff, M. S., Jupiter, H., \& Mokhtar, S. (2021c). Pembudayaan Konotasi "Bahasa Jiwa Bangsa": Refleksi Identiti Kebangsaan Ke Arah Sinergi Solidariti Dan Harmonisasi Rakyat Malaysia. International Journal of Education, Psychology and Counseling, 6 (41), 55-75.

Othman, I. W., Ibrahim, M. A., Esa, M. S., Ationg, R., Mokhtar, S., Mohd Tamring, B. A., \& Sharif Adam, S. D. (2021d). Literasi Undang-Undang Sinonim Kemandirian Jati Diri Mahasiswa dalam Lanskap Politik Kampus: Pemacu Generasi Muda Berjiwa Besar dan Tinggi Karisma Kepimpinan. International Journal of Law, Government and Communication, 6(23), 215-242.

Othman, I. W. (2019a). Kemahiran Penggunaan Bahasa Sebagai Skil Universal dalam Improvasi Keyakinan dan Keterampilan Jati Diri Akademik Ekspatriat di Universiti Awam Malaysia. International Journal of Modern Trends in Social Sciences, 2(10), 91-106.

Othman, I. W., (2019b). Personaliti Optimistik Sebagai Faktor Penentu Adaptasi Sosio Budaya Akademik Ekspatriat di Universiti Awam di Malaysia. Advanced International Journal of Business, Entrepreneurship and SMEs, 1(2), 01-13.

Othman, I. W. (2019c). Signifikasi Struktur Sosial Keluarga dan Hubungan Persahabatan dalam Mempengaruhi Pengalaman Ekspatriasi Ahli Akademik Universiti Awam Malaysia. International Journal of Politics, Public Policy and Social Work, 1(3), 14-31.

Othman, M. K., Mohd Yusoff, M. Z., Abdul Rahim, F., Puteh, A., Kasa, M. D., \& Roslan, N. F. (2016). Perspektif Ibu Bapa Terhadap Permasalahan dan Cabaran dalam Pembentukan Nilai Murni Pelajar. Sains Humanika, 4-2 (2016), 9-16.

Sansalu, D., Esa, M. S., Karulus, Y., \& Mohd Tamring, B. A. (2015). Eksplorasi Hubungan Etnik. Kuala Lumpur: Sasbadi Sdn. Bhd.

Sharif Adam, S. D., Othman, I. W., Hamid, J. A., Esa, M. S., Ationg, R., Lukin, S. A., \& Mohd Tamring, B. A. (2021). Pengaruh Pendidikan dalam Kepelbagaian Etnik Sebelum dan Selepas Merdeka di Malaysia. International Journal of Law, Government and Communication, 6(23), 68-84.

Sharif Adam, S. D. (2019). Peranan dan Cabaran Bahasa Kebangsaan dalam Menyatupadukan Pelbagai Etnik di Sabah. Malaysian Journal of Social Sciences and Humanities, 4(4), $1-11$.

Stapa, Z., Ismail, A. M., \& Yusuf, N. (2012). Faktor persekitaran sosial dan hubungannya dengan pembentukan jati diri. Jurnal Hadhari Edisi Khas, 155-172.

Zakaria, A. R., \& Mohd Salleh, N. (2011). Konteks Keluarga dan Hubungannya dengan Penglibatan Ibu Bapa dalam Pendidikan Anak-Anak di Sekolah Menengah. Jurnal Pendidikan Malaysia, 36(1), 35-44. 